\title{
Job Satisfaction among Teachers Working in Government and Private Schools at Elementary Level
}

\author{
Mehraj Din Dar \\ Research scholar Department of Education University of Kashmir
}

\begin{abstract}
The present study investigates job satisfaction among teachers working in government and private schools. The study is consisted of the teachers of district Ganderbal from both government and private schools. A sample of 100 teachers was selected from government and private schools. It is a descriptive type of research. The questionnaire prepared by Dr. Seema Sanghi was administered to measure the job satisfaction among teachers of government and private schools at elementary level. Data was collected from the related teachers and was analysed using Means, S.D's and $t$-test. The findings of the study reveal that Government teachers at elementary level enjoy better 1. Financial conditions 2. Working conditions and management 3. Job and Personal security and 4. Opportunities for development and promotion as compared to Private school teachers.
\end{abstract}

Keywords: Job satisfaction, government schools, Private schools, Elementary level.

\section{Introduction}

The term job-satisfaction was first of all brought up by Hoppock(1935). Job satisfaction is a very complex and comprehensive phenomena. It can hardly be seen in isolation from life situation. Job satisfaction is widely accepted psychological aspect of functioning in any profession. Happock (1935) reviewed over 30 contemporary studies and concluded that though there was much opinion about jobsatisfaction, yet there was much factual work done in the field.

The term „Job Satisfaction "e is commonly used in the context of human behavior at work. In the words of Feldman and Arnold

"Job satisfaction is the amount of overall positive effect or feelings that individuals have towards their jobs".

Job satisfaction is the amount of pleasure or contentment associated with a job. If you like your intensely, you will experience high job satisfaction. If you dislike your jobs intensely, you will experience job dissatisfaction. Job satisfaction is an individual"s emotional reaction to the job itself. It is his attitude towards his job.

The worst satisfaction of teachers refers to how contented or well pleased they feel about their work and the circumstances surrounding their work. Job satisfaction in short may be defined as how much an individual is adjusted in his work. Satisfaction of today may produce motivation of tomorrow. This is central implication of the relationship of teachers adjustments and teacher satisfaction.

\section{Determinants of Job satisfaction}

Several elements contribute to job satisfaction. These are enumerated below:-

i) Nature of job.

ii) Nature of supervision. iii) Working conditions.

iv) Equitable rewards.

v) Opportunities of promotion.

vi) Co-workers and subordinates.

vii) Job and personal security

viii) Employee morale

Dissatisfaction of an individual whatever may be the occupation in which he is engaged results in professional stagnation. A dissatisfied teacher is lost not only to himself but also to the entire society. A dissatisfied teacher spells disaster to the country"s future. Dissatisfaction among the workers is undesirable and dangerous in any profession. It is just suicidal if it occurs in the teaching profession.

\section{Objectives}

To find and compare the job satisfaction of teachers working in Govt. and private schools with respect to:-

- Financial benefits.

- Non-financial benefits.

- Opportunities for development and promotions.

- Opportunities for responsible and independent work.

- Job and personal security.

- Type or kind of work.

- Job according to interest and abilities.

- Supervisor - supervision and management.

- Recognition and appreciation for accomplishment of job.

- Co-workers and sub-ordinates.

- Working conditions.

\section{Hypothesis}

Govt. school teachers differ significantly as compared to private school teachers in.

- Financial benefits.

- Non-financial benefits.

- Opportunities for development and promotions.

- Opportunities for responsible and independent work. 


\section{International Journal of Science and Research (IJSR) \\ ISSN (Online): 2319-7064}

Index Copernicus Value (2013): 6.14 | Impact Factor (2014): 5.611

- Job and personal security.

- Type or kind of work.

- Job according to interest and abilities.

- Supervisor - supervision and management.

- Recognition and appreciation for accomplishment of job.

- Co-workers and sub-ordinates.

- Working conditions.

\section{Definition of variables}

The term job satisfaction refers to an individuales general attitude towards his or her job. A person with a high level of job satisfaction holds positive attitude about the job, while a person who is dissatisfied with his/her job holds negative attitude about the job. When people speak of employee attitudes, more often than not they mean job satisfaction. Infact the two are frequently used interchangeably. Besides job satisfaction has been defined by various thinkers:

"Job satisfaction is the amount of overall positive effect or feelings that the individuals have towards their jobs".

(D.C. Feldman and H.J. Arnold 1983).

"Job satisfaction is the amount of pleasure or contentment associated with a job. If you like your job intensely, you will experience high job satisfaction. If you dislike your job intensely, you will experience job dissatisfaction".

(Andrew J. DuBrins 1988)

Job satisfaction in the present study refers to the scores obtained by Govt. and private school teachers on Seema Sanghi's Job-value-Questionnaire.

\section{Private schools}

Private schools in the present study shall refer to the schools run by the private management.

\section{Government schools}

Government schools in the present study shall refer to the schools who are under the control of government management.

\section{Delimitation}

The present study of job satisfaction is delimited to the school teachers of Zone-Tulamulla of Ganderbal district.

\section{Design of the study}

\section{Sample}

A sample of 100 teachers from Govt. and Private schools of Zone Tulamulla (Ganderbal) were selected by using a random sampling technique. The selection of the teachers was made as per following procedure:

The investigator first obtained the list of schools from Zone office. It was found that there were approximately 50 schools (middle) in the zone and round about 400 teachers were working in these schools. The investigator decided to draw a sample of 100 teachers (50 each from Govt. and private). In this way the investigator was able to draw 100 teachers:

\begin{tabular}{|c|c|c|}
\hline S.No. & Type of Schools & No. of teachers drawn \\
\hline 01 & Government & 50 \\
\hline 02 & Private & 50 \\
\hline
\end{tabular}

\section{Tool Used}

In the present investigation, the job-value-questionnaire by Seema Sanghi and has been published by Agra psychological corporation. This questionnaire consists of 53 items which finally give 11 factors. The test takes 20-25 minutes for its completion. The eleven factors are explained as:

\section{Factors Area covered}

I. Financial benefits,

II. Non-financial benefits,

III. Opportunities for development and promotions,

IV. Opportunities for responsible and independent action,

V. Job and personal security,

VI. Type and social work,

VII. Job according to interest and abilities,

VIII. Supervisor - supervision and management,

IX. Co worker and subordinates recognition,

X. Appreciation for accomplishment of jobs and

XI. Working conditions.

\section{Scoring}

The cross (X) marking assigned by the respondent at the level of importance is the score of that item. The very high importance denotes 5 scores, high 4, moderate 3, low 2 and very low denotes 1 score. Total score of the item on each factor is the composed score on all the 11 factors separately. The factor wise details are as:-

\begin{tabular}{llll}
\cline { 1 - 2 } Factors & & Items & Total items \\
i) & & $1,12,16,25,37$ & 5 \\
ii) & & $2,26,41,51$ & 4 \\
iii) & $3,14,24,35,50$ & 5 \\
iv) & $4,15,23,36,49$ & 5 \\
v) & $5,13,22,33,42,47,53$ & 7 \\
vi) & $6,17,34,48,52$ & 5 \\
vii) & $7,18,29,39,45$ & 5 \\
viii) & $8,30,40,47$ & 4 \\
ix) & $9,19,31,43$ & 4 \\
x) & $10,20,27,32,38$ & 5 \\
xi) & $11,21,28,44$ & 4
\end{tabular}

\section{Statistical Analysis of Data}

In the present investigation, the investigator has tried to handle the statistical data carefully in order to draw sound interferences. Further in order to realize the objectives of the study, the collected data from the sample of 100 teachers was subjected to statistical analysis. Firstly job value questionnaire by Seema Sanghi (1999) was administered to selected sample. The data collected was arranged in tabulated form, which has been presented as:-

Table 1.00 Significance of difference between the mean scores of teachers of Govt. and private schools on: "Financial Benefits". 


\section{International Journal of Science and Research (IJSR) \\ ISSN (Online): 2319-7064 \\ Index Copernicus Value (2013): 6.14 | Impact Factor (2014): 5.611}

Table 2.00 Significance of difference between the mean scores of teachers of Govt. and private schools on: "Non-financial benefits".

Table 3.00 Significance of difference between the mean scores of teachers of Govt. and private schools on: "Opportunities for Development and promotions".

Table 4.00 Significance of difference between the mean scores of teachers of Govt. and private schools on: "Opportunity for responsible and independent work".

Table 5.00 Significance of difference between the mean scores of teachers of Govt. and private schools on: "Job and personal security".

Table 6.00 Significance of difference between the mean scores of teachers of Govt. and private schools on: "Type and social cast".

Table 7.00 Significance of difference between the mean scores of teachers of Govt. and private schools on: "Job according to interests and abilities".

Table 8.00 Significance of difference between the mean scores of teachers of Govt. and private schools on: "Supervisor-supervision and management".

Table 9.00 Significance of difference between the mean scores of teachers of Govt. and private schools on:"Co-workers and sub-ordinates".

Table 10.00 Significance of difference between the mean scores of teachers of Govt. and private schools on: "Appreciation for accomplishment of job".

Table 11.00 Significance of difference between the mean scores of teachers of Govt. and private schools on: "Working conditions".

Table 1: Showing the Significance of difference between the mean scores of Govt. and private teachers on: "Financial Benefits". (I) ( $\mathrm{N}=50$ each)

\begin{tabular}{|l|l|l|l|l|}
\hline Type of school & $\overline{\mathrm{X}}$ & S.D & t - value & Remarks \\
\hline 1. Government & 21.92 & 1.89 & \multirow{2}{*}{3.21} & $\begin{array}{l}\text { Significant } \\
\text { at } 0.01 \text { level }\end{array}$ \\
\hline 2. Private & 19.96 & 3.98 & &
\end{tabular}

Table 2: Showing the Significance of difference between the mean scores of Govt. and private school teachers on:

"Non-financial aspects". (II) $\mathrm{N}=50$ each

\begin{tabular}{|l|c|r|r|l|}
\hline Type of school & $\bar{X}$ & $S . D$ & t-value & Remarks \\
\hline 1. Government & 14.50 & 2.44 & \multirow{2}{*}{0.48} & Insignificant \\
\hline 2. Private & 14.74 & 2.87 & & \\
\hline
\end{tabular}

Table 3: Showing the Significance of difference between the mean scores of Govt. and private school teachers on:

"Opportunities for Development and Promotions". (III) $\mathrm{N}=$ 50 each

\begin{tabular}{|l|c|c|c|c|}
\hline \multicolumn{1}{|c|}{ Type of school } & $\bar{X}$ & S.D & t-value & Remarks \\
\hline 1. Government & 21.28 & 1.75 & \multirow{2}{*}{2.98} & $\begin{array}{c}\text { Significant at } \\
0.01 \text { level }\end{array}$ \\
\hline 2. Private & 19.64 & 3.56 & & \\
\hline
\end{tabular}

Table 4: Showing the Significance of difference between the mean scores of Govt. and private teachers on:

"Opportunities for responsible and independent works".

(IV) $\mathrm{N}=50$ each

\begin{tabular}{|l|c|c|c|c|}
\hline \multicolumn{1}{|c|}{ Type of School } & $\bar{X}$ & $S . D$ & $t$-value & Remarks \\
\hline 1. Government & 17.82 & 3.01 & \multirow{2}{*}{1.38} & Insignificant \\
\hline 2. Private & 18.72 & 3.55 & & \\
\hline
\end{tabular}

Table 5: Showing the Significance of difference between the mean scores of Govt. and private teachers on: "Job and personal Security". (V) $\mathrm{N}=50$ each

\begin{tabular}{|c|c|c|c|c|}
\hline Type of school & $\bar{X}$ & S.D & $t$-value & Remarks \\
\hline 1. Government & 28.14 & 3.97 & \multirow{2}{*}{2.45} & $\begin{array}{c}\text { Significant at } \\
0.05 \text { level }\end{array}$ \\
\hline 2. Private & 26.00 & 4.80 & & \\
\hline
\end{tabular}

Table 6: Showing the Significance of difference between the mean scores of Govt. and private school teachers on:

"Type or kind of work". (VI) $\mathrm{N}=50$ each

\begin{tabular}{|l|c|c|c|c|}
\hline \multicolumn{1}{|c|}{ Type of school } & $\bar{X}$ & $S . D$ & $t$-value & Remarks \\
\hline 1. Government & 19.30 & 3.73 & \multirow{2}{*}{0.20} & \multirow{2}{*}{ Insignificant } \\
\cline { 1 - 3 } 2. Private & 19.16 & 3.01 & & \\
\hline
\end{tabular}

Table 7: Showing the Significance of difference between the mean scores of Govt. and private teachers on: "Job according to interest and abilities". (VII) $\mathrm{N}=50$ each

\begin{tabular}{|l|c|c|c|c|}
\hline \multicolumn{1}{|c|}{ Type of school } & $\bar{X}$ & S.D & t-value & Remarks \\
\hline 1. Government & 21.02 & 2.96 & \multirow{2}{*}{1.25} & Insignificant \\
\hline 2. Private & 20.24 & 3.32 & & \\
\hline
\end{tabular}

Table 8: Showing the Significance of difference between the mean scores of Govt. and private teachers on:

"Supervisor - supervision and management". (VIII) $\mathrm{N}=50$

\begin{tabular}{|l|c|c|c|c|}
\multicolumn{1}{|c|}{ Type of school } & $\bar{X}$ & S.D & $t$-value & Remarks \\
\hline 1. Government & 16.36 & 2.34 & \multirow{2}{*}{4.47} & $\begin{array}{c}\text { Significant at } \\
0.01 \text { level }\end{array}$ \\
\hline 2. Private & 14.48 & 2.06 & &
\end{tabular}

Table 9: Showing the Significance of difference between the mean scores of Govt. and private teachers on:"Coworker and sub-ordinates". (IX) $\quad \mathrm{N}=50$ each

\begin{tabular}{|l|c|c|c|c|}
\hline \multicolumn{1}{|c|}{ Type of school } & $\bar{x}$ & S.D & $\mathrm{t}-$ value & Remarks \\
\hline 1. Government & 16.74 & 3.19 & \multirow{2}{*}{0.64} & Insignificant \\
\hline 2. Private & 16.40 & 2.13 & & \\
\hline
\end{tabular}

Table 10: Showing the Significance of difference between the mean scores of Govt. and private school teachers on:

"Recognition, appreciation for accomplishment". (X) N= 50 each

\begin{tabular}{|l|c|c|c|c|}
\hline \multicolumn{1}{|c|}{ Type of school } & $\bar{X}$ & S.D & t - value & Remarks \\
\hline 1. Government & 18.56 & 3.91 & 0.32 & Insignificant \\
\cline { 1 - 3 } 2. Private & 18.78 & 2.75 & & \\
\hline
\end{tabular}

Table 11: Showing the Significance of difference between the mean scores of Govt. and private school teachers on:

"Working conditions". (XI) N=50 each

\begin{tabular}{|l|c|c|c|c|}
\hline \multicolumn{1}{|c|}{ Type of school } & $\bar{X}$ & S.D & $t$-value & Remarks \\
\cline { 1 - 3 } 1. Government & 16.24 & 1.72 & \multirow{2}{*}{3.52} & $\begin{array}{c}\text { Significant at } \\
0.01 \text { level }\end{array}$ \\
\cline { 1 - 3 } 2. Private & 15.04 & 1.69 & & \\
\hline
\end{tabular}




\section{Interpretation of the Results}

Following are the areas covered in the present investigation:

1. Financial benefits

2. Non-financial benefits.

3. Opportunities for development and promotions.

4. Opportunities for responsible and independent work.

5. Job and personal security.

6. Type or kind of work.

7. Job according to interest and abilities.

8. Supervisor - supervision and management.

9. Recognition and appreciation for accomplishment of job.

10. Co-workers and sub-ordinates and 11. Working conditions.

In the present study the main focus was to find and compare the job-satisfaction of teachers working in Govt. and private schools at elementary level.

In order to realize this objective the data has been collected and arranged in tabular form. The interpretation and discussion of the results based on this tabulated data is presented as under.

From table 1.00 , it is revealed that there is significant difference between the mean scores of the teachers of Govt. and private schools in factor I i.e., Financial - benefits. This difference has been found significant at 0.01 level $(\mathrm{t}=3.21)$. It is inferred that teachers working in the Govt. schools are enjoying more financial benefits as compared to teachers working in private schools.

Table 2.00 reveals that there is no significant difference between the mean scores of teachers of Govt. and private schools in factor II i.e., Non-financial benefits $(\mathrm{t}=0.48)$, which means that teachers from private and Govt. schools have equal chances of non-financial benefits.

A perusal of Table 3.00 reveals that there is a significant difference between the mean scores Govt. and private teachers in factor iii (opportunities for development and promotions). This difference has been found significant at 0.01 level $(\mathrm{t}=2.98)$. it may be said that, the Govt. teachers have better opportunities for development and promotions as compared to teachers working in private schools.

Table 4.00 reveals that there is no significant difference between the mean scores of Govt. and private teachers in factor iv i.e., opportunities for responsible and independent work. $(t=1.38)$. The $t$-value suggests that the Govt. as well as private school teachers have equal chances for responsible and independent work.

A close look at Table 5.00 signifies the difference between the mean scores of Govt. and private teachers in factor v i.e., job and personal security. The difference has been found to be significant at 0.05 level $(\mathrm{t}=2.45)$. The $\mathrm{t}$ value indicates that teachers of Govt. schools enjoys better jobs and personal security as compared to teachers of private schools.

Table 6.00 reflects that there is no significant difference of Govt. and private school teachers in the factor vi i.e., type or kind of work $(t=0.20)$, which reveals that private school teachers have equal chances of type or kind of work as Govt. teachers have.

Table 7.00 also doesn't shows any significant difference between the mean scores of Govt. and private school teachers in the factor vii i.e., job according to interest and abilities. $(\mathrm{t}=1.25)$. The $\mathrm{t}$-value suggests that private school teachers also have equal chances for job according to their interests and abilities.

Table 8.00 signifies that difference between the mean scores of teachers from Govt. and private schools in the factor viii i.e., Supervisor- supervision and management. This difference has been found significant at 0.01 level $(\mathrm{t}=4.47)$. The t-value reveals that Govt. school teachers experiences better supervision and management as compared to teachers working in private sector.

Table 9.00 shows that there is no significant difference between the mean scores of teachers of Govt. and private schools in factor ix i.e., Co-workers and sub-ordinates. $(\mathrm{t}=$ 0.64). The t-value clearly indicates that the private school teachers have equal chances of respect and appreciation from co-workers and sub-ordinates as is enjoyed by Govt. school teachers.

Table 10.00 does not shows any significant difference between the mean scores of Govt. and primary school teachers in factor $\mathrm{x}$ i.e., Recognition, Appreciation for accomplishment of Job. $(\mathrm{t}=0.32)$ Here $\mathrm{t}$-value suggests that private school teachers also equal chances for recognition. Appreciation for accomplishment of job.

Table 11.00 shows significant difference between the mean scores of Govt. and private school teachers on working conditions i.e., factor xi. The difference has been found significant at 0.01 level $(\mathrm{t}=3.25)$. The $\mathrm{t}$-value clears that teachers working in Govt. schools enjoys better working conditions than those working in private schools.

From the above discussions it is quite evident that Govt. teachers at elementary level enjoy better:-

i) Financial conditions,

ii) Working conditions,

iii) Supervision and management,

iv) Job and personal security and

v) Opportunities for development and promotions.

As compared to private schools teachers at the same level.

\section{Conclusions and Suggestions}

The present study was undertaken with the main objectives of studying job-satisfaction among teachers of Government and private schools with respect to:

- Financial benefits.

- Non-financial benefits.

- Opportunities for development and promotions.

- Opportunities for responsible and independent work.

- Job and personal security.

- Type or kind of work.

- Job according to interest and abilities.

- Supervisor - supervision and management. 


\section{International Journal of Science and Research (IJSR) \\ ISSN (Online): 2319-7064}

Index Copernicus Value (2013): 6.14 | Impact Factor (2014): 5.611

- Recognition and appreciation for accomplishment of job.

- Co-workers and sub-ordinates.

- Working conditions.

On the basis of the interpretation of results, the following conclusions are drawn:-

1. Govt. school teachers have been found satisfied with their jobs on the following factors:-

- Financial benefits,

- Opportunities for development and promotions,

- Job and personal security,

- Supervisor - supervision and management,

- Working conditions.

2. Private school teachers have been satisfied with their jobs on the following factors:-

- Non-financial benefits.

- Opportunities for development and promotions.

- Type or kind of work.

- Job according to interest and abilities.

- Recognition and appreciation for accomplishment of job.

- Co-workers and sub-ordinates.

3. Govt. school teachers have not been satisfied with their jobs on the following factor(s) as compared to private school teachers:-

- Non-financial benefits.

- Opportunities for development and promotions.

- Type or kind of work.

- Job according to interest and abilities.

- Recognition and appreciation for accomplishment of job.

- Co-workers and sub-ordinates.

4. Private school teachers have not been found satisfied with their jobs on the following factors:-

- Financial benefits,

- Opportunities for development and promotion,

- Job and personal security,

- Supervisor - supervision and management and

- Working conditions.

\section{Suggestions}

On the basis of the findings of the present study, the investigator feels that the following suggestions be taken into consideration while conducting a study similar to present one:-

a) The study on job satisfaction of teachers working in different schools/colleges should be conducted on larger sample.

b) The present study be conducted according to the residential dichotomy of teachers.

c) The present study should be conducted at different levels viz., primary, elementary and higher level.

The study should be undertaken on teacher trainees of different colleges

\section{References}

[1] Abraham, Amit. (1994) Job satisfaction and Teacher Effectiveness: A study on college teachers, Indian journal of psychometry and education. Vol.25 (1\&2), 61-64, (IEA, July

[2] Agarwal, Meenakshi(1991) Job satisfaction of teachers in relation to some demographic variables and values. Ph.D Edu.Agra University.

[3] Anand S.P. (1987) Personality factors and job satisfaction, Indian education Review, Vol. XXII, No.1 (NCERT)

[4] Anand. S. P.(1972) School teachers and job satisfaction, Teacher Education Vol.8,No. 1, p.p 16-23.

[5] Bhatt., D.J. (1997) Job stress, job involvement and job satisfaction: A correalational study. Indian journal of psychometry and education, Vol. 28(2), 87-94 (IEA, Vol.1, No.1, Jan 2001).

[6] Chopra, R,K. (1990) Institutional climate and teachers job satisfaction. Indian Education Review, Vol. XXI, No.2, April. 1990. (NCERT).

[7] Chopra, R,K. (1990) Institutional climate and teachers job satisfaction. Indian Education Review, Vol. XXI, No.2, April. 1990.

[8] Goyal. G.C (1980) A study of relation among Attitude, job satisfaction, Adjustment and professional interest of teacher education In India, Ph. $\mathrm{D}$ thesis, Delhi University.

[9] Gupta, S. P (1980) A study of job satisfaction at three levels Ph. D. Edu. Mee University.

[10] Hoppock, R ( 1935) Job satisfaction, New York: Harper \& Bros. 